\title{
PENYALAHGUNAAN NARKOBA SEBAGAI KEJAHATAN TERHADAP HAK ASASI MANUSIA YANG BERDAMPAK TERHADAP KEBERLANGSUNGAN HIDUP MANUSIA
}

\author{
Mohammad Indra Bangsawan \\ Fakultas Hukum Universitas Muhammadiyah Surakarta \\ Jl. A. Yani Tromol Pos I, Pabelan, Kartasura
}

\begin{abstract}
$D$ rug abuse is a complex problem and has a broad dimension, both from a medical, psychiatric, mental health, and psychosocial. The types of drugs that are commonly abused narcotics, psychotropic and other addictive substances, or substances that can cause addiction and dependency. Presence of Drugs in the world has two paradoxical side (the opposite). On the one hand, a drug very useful, especially medicine, pharmacy, medicine, and so on. But on the other hand drug abuse can threaten the survival of humans, especially for the younger generation in the future. Drug abuse is a threat to human survival clearly have violated human rights to carry out the work and enjoy the freedom of life that is oriented to things that are positive. Based on Data ages 15-64 by 2015 World drug report, UNODC (United Nations Office on Drugs and Crime) said that the number of drug users in 2006 based on the data is 208 million, and rose sharply in 2013 as many as 246 million, this figure will be more complete with data from the same source that states that the number of problematic drug abuse in 2006 touched the figure of 26 million, and by 2013 is likely to increase widened to 27.4 million. Cases of drug abuse among the youth students to dot the main focus, although many victims of drug abuse in addition to students, but focus on them is the most crucial, because students ever abusing drugs will be a source of major catastrophe for nations around the world. The threat of drug abuse clearly is multi-dimensional: health, economic, social, and education, security and law enforcement. The danger of drug abuse will have an impact on the health, physical and psychological deterioration, damage the generation, dependency and even death. The problem of drug abuse is a central issue in human sustainable of development, should be a central issue in various dialogues drugs. There will be no socio-economic growth, if drug abuse is increasing and getting worse, which in turn affect the survival of the young generation.
\end{abstract}

Key words: Drug abuse, human rights, the younger generation.

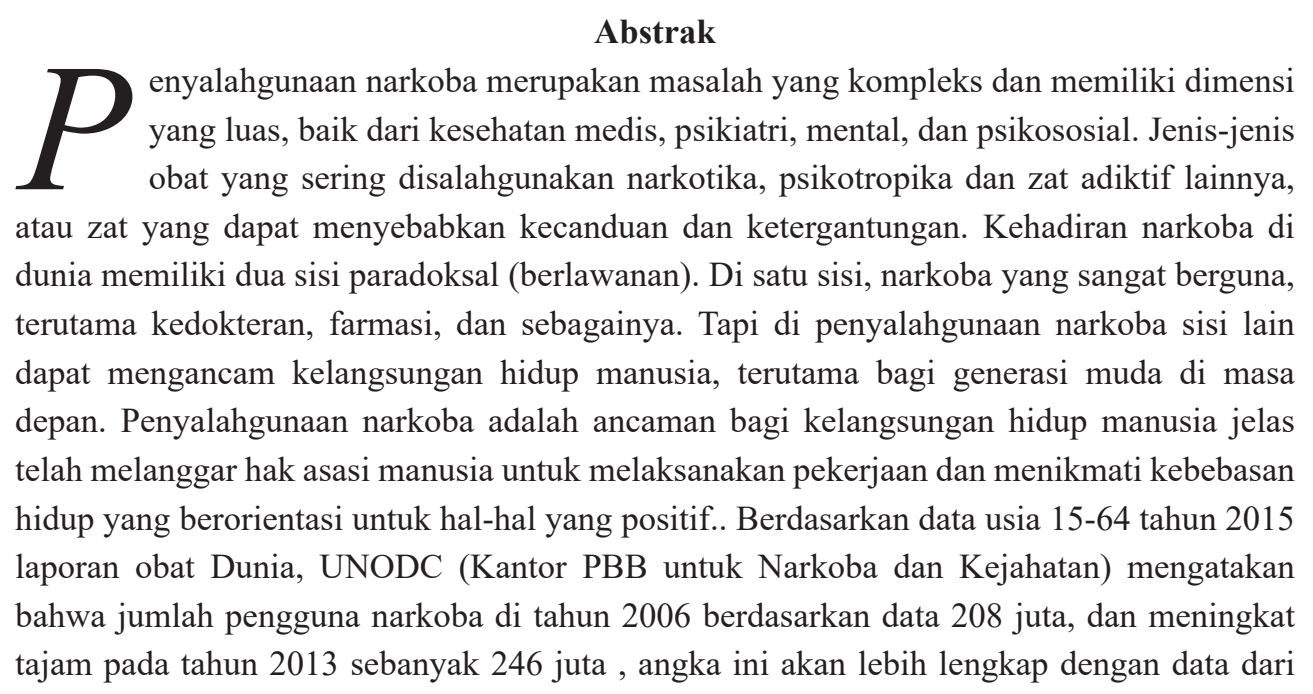


sumber yang sama yang menyatakan bahwa jumlah penyalahgunaan narkoba bermasalah pada tahun 2006 menyentuh angka 26 juta, dan pada tahun 2013 cenderung meningkat dan melebar menjadi 27,4 juta. Kasus penyalahgunaan narkoba di kalangan mahasiswa sebagai pemuda dan siswa menjadi fokus utama, meskipun banyak korban penyalahgunaan narkoba di samping siswa, tetapi fokus pada mereka adalah yang paling penting, karena siswa yang pernah menyalahgunakan obat akan menjadi sumber bencana besar bagi negaranegara di dunia. Ancaman penyalahgunaan narkoba jelas adalah multi-dimensi: kesehatan, ekonomi, sosial, dan pendidikan, keamanan dan penegakan hukum. Bahaya penyalahgunaan narkoba akan berdampak pada kesehatan, kerusakan fisik dan psikologis, merusak generasi, ketergantungan dan bahkan kematian. Masalah penyalahgunaan narkoba merupakan masalah sentral dalam pembangunan manusia yang berkelanjutan yang harus menjadi isu sentral di berbagai dialog narkoba. Karena memang tidak akan ada pertumbuhan sosial-ekonomi yang baik, jika penyalahgunaan narkoba meningkat dan semakin parah, yang pada gilirannya mempengaruhi kelangsungan hidup generasi muda.

Kata kunci: Penyalahgunaan narkoba, hak asasi manusia, generasi muda.

\section{Pendahuluan}

\section{Latar Belakang}

Dewasa ini, perkembangan kejahatan narkoba telah menakutkan kehidupan masyarakat yang telah memakan beribu-ribu korban, tanpa memandang umur dan status sosial. Ironisnya, yang menjadi korban mayoritas adalah kalangan remaja dan pemuda yang merupakan generasi penerus bangsa. Fenomena ini menyadarkan kita bahwa penyalahgunaan narkoba merupakan tanggungjawab negara dan masyarakat. Oleh karena itu, perlu adanya penanggulangan narkoba secara komprehensif dengan menitikberatkan serta masyarakat serta pengembangan sikap para penegak hukum secara intensif. Dengan mengemukakan permasalahan yang sedang dihadapi oleh Bangsa-bangsa di seluruh dunia, termasuk Bangsa Indonesia yang berhubungan dengan penyalahgunaan narkoba. Masalah merebaknya penyalahgunaan narkotika dan obat-obat berabahaya (narkoba) kian hari kian meningkat. Walaupun, disatu sisi pemerintah secara aktif melakukan penggrebekan dan penangkapan, akan tetapi tampaknya belum juga mereda, bahkan dapat dikatakan masih belum dapat diatasi. Menurut informasi akhir-akhir ini Berdasarkan data usia 15-64 tahun 2015 laporan UNODC (Kantor PBB untuk Narkoba dan Kejahatan) mengatakan bahwa jumlah pengguna narkoba di tahun 2006 berdasarkan data yang 208 juta, dan meningkat tajam pada tahun 2013 sebanyak 246 juta, angka ini akan lebih lengkap dengan data dari sumber yang sama yang menyatakan bahwa jumlah penyalahgunaan narkoba bermasalah pada tahun 2006 menyentuh angka 26 juta, dan pada tahun 2013 cenderung meningkat melebar menjadi 27,4 juta. usaha untuk mengatasi permasalahan penyalahgunaan narkoba memang merupakan hal yang tidak mudah untuk dilaksanakan. Meskipun demikian, demi Negara, Bangsa dan Tanah Air kita, maka tantangan ini harus kita hadapi walaupun dalam keadaan yang sangat sulit sekalipun, karena masa depan setiap bangsa di seluruh dunia berada di tangan mereka sebagai penerus dan mempertahankkan keberlangsungan hidup umat manusia.

Dunia telah melakukan upaya-upaya terkait dengan penyalahgunaan narkoba, antaralain dengan terselenggaranya konferensi tentang psikotropika yang pertama kali diselenggarakan oleh The United Nation Conference For The Adoption Of Protocol On Psychotropic Substances mulai tanggal 11 januari-21 februauri 1971, di Wina Austria, telah menghasilkan Convention Psyhcotropic Substance 1971. Sebagai sautu perangkat hukum internasional, konvensi tersebut mengatur kerjasama internasional dalam pengendalian dan pengawasan produksi, peredaran dan penggunaan psikotropika, serta mencegah terhadap penyalahgunaannya dengan pemberian batasan hanya bagi kepentingan kepentingan pengobatan dan ilmu pengetahuan. 
Penyalahgunaan Narkoba dan Psikotropika dengan cara mengedarkan dan memberdagangkannya dapat digolongkan dalam kejahatan internasional. Pengertian kejahatan internasional berdasarkan salah satu resolusi yang diadopsi oleh Ninth United of Offenders di Cairo pada tanggal 29 April-8 Mei 1995, yakni: resolusi tentang internasional instrumens, such as convention or convention against transnational crimes. Hal ini merupakan tindak lanjut dari world ministerial Conference on Organized Transnationnal Crime yang diselenggarakan di Napoli pada tanggal 21-23 November 1994. Kejahatan Internasional ini membuktikan adanya kuantitas dan kualitas kejahatan ke arah organisasi kejahatan transnaional, melewati batas-batas dan menunjukan kejra sama yang bersifat reginal maupun internasional ${ }^{1}$.

Terhadap kejahatan hak asasi manusia, perlu di garis bawahi dahulu mengenai definisi dari pada kejahatan dan hak asasi manusia yang akan direlasikan dengan penyalahgunaan narkoba. Secara umum kejahatan sendiri memiliki pengertian sebagai suatu/tindakan anti sosial yang merugikan, tidak pantas, tidak dapat dibiarkan, yang dapat menimbulkan kegoncangan dalam masyarakat. ${ }^{2}$ Sedangkan Hak Asasi Manusia merupakan pemberian dari Allah SWT, sebagai konsekuensi dari manusia adalah ciptaan Allah SWT, sehingga tidak dapat dirampas atau dihapuskan oleh negara. Jika suatu Negara dalam kondisi tidak normal atau dalam keadaan darurat, negara diperbolehkan melakukan tindakan yang bersifat luar biasa termasuk melakukan pembatasan terhadap hak asasi manusia demi mempertahankan integritas Negara dan melindungi warga negaranya. Dengan demikian, penyalahgunaan narkoba sebagai kejahatan hak asasi manusia mengandung arti bahwasannya segala bentuk penyalahgunaan narkoba dapat dikategorikan sebagai sebuah kejahatan yang merugikan dan dapat menimbulkan kegoncangan dalam masyarakat yang secara tidak langsung akan mengancam hak-hak asasi manusia lainnya dalam pergaulan hidup masyarakat dan akan mempengaruhi keberlangsungan dan eksistensi umat manusia kedepannya.

\section{Rumusan Masalah}

Bagaimana hubungan penyalahgunaan narkoba sebagai kejahatan hak asasi manusia yang berdampak terhadap keberlangsungan hidup manusia?

\section{METODE PENELITIAN}

Metode penelitian ini menggunakan metode penelitian komparatif yang mencari jawaban secara mendasar tentang sebab-akibat, dengan menganalisa faktor-faktor penyebab terjadinya ataupun munculnya suatu fenomena tertentu, dan bersifat ex post facto Artinya, data dikumpulkan setelah semua kejadian yang dikumpulkan telah selesai berlangsung. Peneliti dapat melihat akibat dari suatu fenomena dan menguji hubungan sebab akibat dari data-data yang tersedia. ${ }^{3}$

\section{Pembahasan}

\section{Penyalahgunaan Narkotika dan Obat Terlarang}

Penyalahgunaan narkoba bukanlah suatu kejadian sederhana yang bersifat mandiri, melainkan merupakan akibat dari berbagai faktor yang secara kebetulan terjalin menjadi suatu fenomena yang sangat merugikan bagi semua pihak yang terkait. Faktor individu dan faktor lingkungan hiduo yang saling berkaitan erat, berjalan berbarengan dan berperan dalam proses tumbuh kembang sesirang mengiktui berjalannya waktu, sampi individu menemukan bentuk kehidupannya. Faktor individu dan faktor lingkungan memounyai andil yang sama besarnya

1 Sunarso, Siswantoro. 2004. Penegakan Hukum Psikotropika Dalam Kajian Sosiologi Hukum. Jakarta: Raja Grafindo Persada. Hlm 2.

2 B. Simanjuntak. 1981. Beberapa Aspek Patologi Sosial. Bandung: Alumni. Hlm. 176

3 Nazir, Moh. 1998. Metode Penelitian. Jakarta: ghalia Indonesia. Hlm. 63 
did dalam terjadinya penyimpangan perilaku seseorang dari norma-norma yang berlaku di dalam komunitasnya. ${ }^{4}$

Setiap negara-negara di dunia berada dalam posisi saat usaha untuk mewujudkan masyarakat yang sejahtera. Akan tetapi, timbul beberapa masalah sosial yang tampil dalam wujud individu tetap juga dapat pula tampil dalam level masyarakat atau sistem. Sehubungan dengan hal itu, sebagai bagian dari sumber daya manusia, warga masyarakat penyandang masalah penyalahgunaan kecanduan obat tidak diharapkan tampil dalam kapasitas yang maksimal. Dengan demikian, potensinya juga tidak dapat di aktualisasikan secara optimal dalam proses yang sedang berjalan. Bahkan dalam kondisi lebih parah, penyandang masalah tersebut bukan saja tidak optimal sumbangannya terhadap proses, melainkan justru dapat manjadi beban yang bersifat counter productive. ${ }^{5}$ Sebagai ilustrasi, rata-rata keluarga di Amerika Serikat, menyimpan sekitar 30 jenis obat-obatan di dalam lemari obat dan sejumlah minuman beralkohol di lemari minuman. Permasalahannya kemudian dapat berakibat pada kebiasaan mabuk dan teler yang dalam jangka panjang bersifat merugikan baik secara fisik, psikologis dan sosial. Bahkan dalam proses lebih lanjut kebiasaan tersebut tidak saja mengakibatkan seseorang menjadi mabuk dan teler tetapi juga mengakibatkan kecanduan, kecanduan adalah suatu proses seperti yang sudah diuraikan sebelumnya, yaitu penyalahgunaan dan pemakai berlebihan yang mengakibatkan seseorang menjadi tidak berdaya, dalam pengertian kondisi tersebut akan bersifat mengendalikan orang yang bersangkutan, membuatnya berbuat dan berpikir beroperasi tidak konsisten dengan nilai-nilai kepribadiannya dan mendorong orang tersebut menjadi semakin kompulsif dan obsesif. ${ }^{6}$

Perilaku penyalahgunaan obat dan kecanduan obat memang merupakan deviasi pada level individu, walaupun demikian, sumber permasalahannya dapat berasal dari faktor individual maupun dari masyrakat atau sistem. Seperti dikemukakan oleh Eitzen dalam buku yang ditulis oleh Soetomo, ada lima variasi perilaku individu yang menyimpang dilihat dari sumber masalahnya, kelima variasi tersebut adalah:

a. Terjadi pelanggaran norma dan nilai sosial oleh individu,

b. Persepsi individu ynag didasarkan pada proses sosialisasi,

c. Masyarakat yang memberikan label seseorang sebagai devian,

d. Peranan dari kekuatan dominan dalam proses kehidupan masyarakat,

e. Struktur masyarakat sendiri yang menyebabkan sesorang warganya deviasi(penyimpangan), ${ }^{7}$

Adanya perubahan perilaku untuk menjadi pecandu penyalahgunaan narkoba dikarenakan beberapa alasan. Jika kita melihat teori Kelman, Menurut Kelman, ada tiga cara terjadinya perubahan parilaku, yaitu:

a. Karena Terpaksa

Pada cara ini, individu mengubah perilakunya dikarenakan mengaharapkan akan:

a. Memperoleh imbalan, baik materi maupun non-materi,

b. Memperoleh pengakuan dari kelompoknya,

c. Terhindar dari hukuman,

d. Tetap terpelihara hubungan baik

b. Karena ingin meniru atau ingin dipersamakan.

Pada cara ini, individu mengubah perilakunya karena ingin dipersamakan dengan orang yang dikaguminnya

4 Yanny,L.Dewi. 2002. Narkoba, Pencegahan dan Penangannya. Jakarta: Elex Media Komputindo. Hlm. 29

5 Soetomo. 2008. Masalah Sosial dan Upaya Pemecahannya. Yogyakarta: Pustaka Belajar: Hlm. 340

6 Soetomo. 2008. Masalah Sosial dan Upaya Pemecahannya. Yogyakarta: Pustaka Belajar: Hlm. 343

7 Ibid. Hlm 347 
c. Karena menyadari manfaatnya.

Pada cara ini perubahan benar-benar mendasar; artinya benar-benar menjadi bagian hidupnya. ${ }^{8}$

Berkaitan dengan Hak asasi manusia, Penyalahgunaan narkoba jelas merupakan sebuah kejahatan terhadap hak asasi manusia. Hak-hak asasi pokok manusia, semata-mata ada karena dirinya manusia terdiri atas hak untuk untuk hidup, hak untuk keselamatan hidup, penghormatan terhadap kesucian kaum wanita, hak untuk memperoleh kebutuhan pokok, hak individu atas kebebasan, hak atas keadilan, kesamaan derajat umat manusia, dan hak untuk kerja sama dan tidak bekerja sama. ${ }^{9}$ Semua hak-hak tersebut tidak akan berpengaruh terhadap mereka yang telah menjadi pecandu penyalahgunaan narkoba, karena seluruh masyarakat yang berada disekitarnya menjadi tidak aman dan hidup dalam pengekangan. Dalam kondisi faktual, berdasarkan jumlah pengguna narkoba di Indonesia dari badan narkotika Nasional Indonesia ${ }^{10}$ dan laporan UNODC $2015^{11}$, dalam hal ini sesuai dengan tingkat pendidikan dan Umur.

2. Hubungan penyalahgunaan narkoba sebagai kejahatan hak asasi manusia yang berdampak terhadap keberlangsungan hidup manusia.

Narkoba ( Narkotika dan obat berabahaya) adalah semua bahan obat yang mempunyai efek kerja yang bersifat membiuskan menurunkan kesadaran (depressant), merangsang meningkatkan prestasi (stimulans), menagihkan ketergantungan (dependence), menghayalkan (halusinasi). Fenomen sosial ini sangat membahayakan eksistensi suatu bangsa, karena meracuni jiwa pemuda sehingga seluruh dunia akan dibayangi dengan ketakutan. ${ }^{12}$ Disamping mengancam kesehatan mental individu anggota masyarakat, penyalahgunaan narkoba merupakan sebuah kejahatan yang mengancam hak-hak asasi manusia lainnya, sehingga eksistensi terhadap manusia, bangsa dan negara menjadi taruhannya.

Berkaitan dengan penyalahgunaaan narkoba, mempelajari kriteria dan jenis-jenis narkoba merupakan salah satu hal yang penting untuk dijadikan bahan referensi. Menurut Verdovende Middlen Ordonansi, maka yang termasuk dari jenis Narkoba antara lain :

a. Ruw Opium (Opium mentah); diambil dari buah tanaman papaver.

b. Bereid Opium (Opium masak); candu

c. Medisinaal Opium (candu yang telah diolah menjadi obat)

d. Morphine; ( C17HH19NO3)

e. Diacetymohine: diamorpjine (heroin) (C12H23NO5)

f. Ruw cocaine (cocaine mentah) diambil dari daun coca

g. Ecgunine: dari daun coca.

h. Cocaine.

i. Getah dari Indische Hannep (ganja).

j. Obat-obat dari berupa extract atau tinctur. Dari jenis ini dapat dibagi dalam klassifikasi:

1) Dari alamiah (natural) :

a) Candu, morphine, heroin

b) Getah dari (ganja) tanaman Cannabis sativa : Maryjuana

c) Cocaine, ecgonine, codein.

8 Retnaningsih, Ekowati. 2013. Akses Layanan Kesehatan. Depok: Rajagrafindo. Hlm. 66.

9 Green Mind Community. 2009. Teori dan Politik Hukum. Yogyakarta: Total Media. Hlm. 270

10 Badan Narkotika Nasional. Pelajar dan Bahaya Narkotika. Jakarta: BNN. 2010

11 UNODC.World Drug Report in 2015

12 B. Simanjuntak. 1981. Beberapa Aspek Patologi Sosial. Bandung: Alumni. Hlm. 124 
2) Dari sintesis :

a) L.S.D (Lisergie Acid Diethilamide)

b) D.M.T. (Dimethyl tryptmanie)

c) D.E.T. (Diethyl tryptamanie)

d) Methodone, Meporidine, Hydremorphone. ${ }^{13}$

Setelah mengetahui jenis-jenis narkoba yang termuat diatas, timbul sebuah pertanyaan tentang bagaimana proses kejiwaan yang dialami oleh para pecandu?. Pada dasarnya ada beberapa tahap yang terjadi jika seseorang telah terindikasi mengonsumsi barang haram tersebut, yaitu tahap euphorlia, halusinasi, delirium, weaknesa, drawsines. ${ }^{14}$ Perlu dititik tekankan bahwa pada tahap delirium ini sangat kruasial, karena segala cara bagi mereka yang telah menjadi candu akan ditempuh untuk mendapatkan ganja baik dengan membunuh, mencuri uang, merampok dan segala bentuk kejahatan kriminal lainnya yang mengancam dan merugikan masyarakat.

Berkaca terhadap sejarah, masalah narkotik dimulai sejak timbulnya perang saudara di Amerika $^{15}$. Ada kesejajaran masalah narkotik dengan situasi perang karena nerkotik bersifat psyshotropic subtances (merubah jiwa) sesuai dengan tuntutan situasi perangm antara lain meninggikan prestasi, merendahkan ketahanan tempur pihak lawan. Inilah sebabnya pada kesempatan malam pertemuan Nasser Dan Chou En Lai Tahun 1965, Chou Berkata : tidak suka bahwa amerika menarik pasukannya dari Vietnam karena sebagian besar pasukan Amerika sudah terjaring ketagihan air minum candu. Mudah-mudahan pasukan Amerika semakin banyak datang ke Vietnam agar Kami berkesempatan merusak rakyat moral yang amerika lewat pasukannya. Tidak terbayangkan dahsyatnya untuk rakyat Amerika, Karena pada Tahun 1968 ternyata Korban candu di amerika Meningkat 40\%. Indonesia Ikut kelabakan Sekarang. Pada tahun 1968 Direktur Rekrim Mabak Masih menanggapi narkotik Belum Menjadi masalah untuk Indonesia. Tetapi Bukti Sekarang Sudah Menjadi masalah Utama. Dimana-mana ganja disita antara lain Medan, Bandung, Surabaya, apalagi JAKARTA. Yang tidak disangka pulau Bali, 30\% puntung Rokok di Hotel Berisi ganja heroin Dan Morphin. Kota besar di Indonesia menunjukkan bahwa telah ada generasi muda yang mengasingkan diri dari aktivitas masyarakat, meniru Masyarakat Hippies. ${ }^{16}$

Mengapa justru sekarang masalah narkotik ini menjadi problem? Sebab dulupun orang yang lanjut usia sudah banyak yang terserang candu, tetapi tidak menjadi masalah, setidaktidaknya tidak dipermasalahkan orang. Hal ini disebabkan korban narkotik dewasa ini ialah anak remaja yang sedang mencari identititas, harapan bangsa, penerus generasi, pemimpin dikemudian hari. ${ }^{17}$ Badan Narkotika Nasional tahun 2009 memproleh data bahwa rata-rata usia pertama kali menyalahgunakan narkoba pada usia yang sangat muda yaitu 12-15 tahun, sasaran pertama penyalahgunaan narkoba sekarang bukan hanya orang-orang yang telah dewasa, tapi juga para pelajar yang masih dalam masa pertumbuhan, hal ini dibuktikan dengan angka pertumbuhan nakotika dikalangan pelajar untuk pertama kali mencoba narkoba sebesar 7,5 persen dan setahun pakai sebesar 4,7 persen. ${ }^{18}$ Tahun 2013, BNN kembali mengeluarkan Data yang menunjukan bahwa Presentasi pengguna narkoba tertinggi adalah Pelajar SMA yakni sebanyak 19.730

\footnotetext{
13 B. Simanjuntak. 1981. Beberapa Aspek Patologi Sosial. Bandung: Alumni. Hlm. 129-130.

14 Ibid. Hlm. 131.

15 Wikipedia. 2016. "Perang Saudara Amerika Serikat" (online), ( https://id.wikipedia.org/wiki/Perang_Saudara_ Amerika_Serikat.htm, diakses tanggal 31 Mei 2016).

16 Hippie adalah sebuah kultur yang muncul di Amerika Serikat sekitar tahun pertengahan 1960an. Wikipedia. 2016. "Hippie" (online), (https://id.wikipedia.org/wiki/Hippie.htm, diakses tanggal 31 Mei 2016).

17 B. Simanjuntak. 1981. Beberapa Aspek Patologi Sosial. Bandung: Alumni. Hlm. 124-125

18 Badan Narkotika Nasional. 2010. Pelajar dan Bahaya Narkotika. Jakarta: BNN. Hlm. 3.
} 


\section{The number of drug users by level of education}

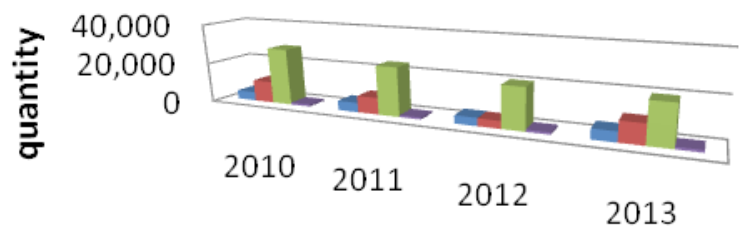

\begin{tabular}{|c|c|c|c|c|}
\hline & 2010 & 2011 & 2012 & 2013 \\
\hline Elementary School & 4,404 & 4,753 & 4,012 & 4,980 \\
\hline - Junior High School & 10,877 & 8,322 & 3,768 & 9,768 \\
\hline - Senior High School & 28,476 & 24,328 & 20,503 & 19,730 \\
\hline College & 1,001 & 992 & 1,124 & 1,162 \\
\hline
\end{tabular}

Tabel 1. Pengguna Narkoba Berdasarkan Kelompok Usia

\begin{tabular}{cccccccc}
\hline \multirow{2}{*}{ No } & Age & \multicolumn{3}{c}{ Male } & \multicolumn{3}{c}{ Female } \\
\cline { 3 - 8 } & group & Min Value & Max Value & $\%$ & Min Value & Max value & \% \\
\hline 1 & $10-19$ & 784.597 & 800.759 & 3,4 & 211.734 & 216.677 & 1,0 \\
2 & $20-29$ & 1.434 .692 & 1.474 .794 & 7,2 & 368.972 & 376.930 & 1,8 \\
3 & $30-39$ & 619.895 & 641.745 & 3,2 & 94.977 & 97.262 & 0,5 \\
4 & $40++$ & 586.418 & 607.425 & 1,8 & 113.965 & 117.821 & 0,3 \\
& Total & 3.425 .602 & 3.524 .723 & - & 789.648 & 808.690 & - \\
\hline
\end{tabular}

Berhubungan dengan kejahatan narkoba, Dewan Pusat Stastistik 2014 dirilis data yang jahat narkotika mencapai 19,953 kasus. Wilayah terbesar adalah dalam lingkup Polda Metro Jaya sebagai banyak kasus kejahatan narkoba 5.400

Tabel 2. Data crimes against drugs in each province of Indonesia. ${ }^{19}$

\begin{tabular}{clc}
\hline No & \multicolumn{1}{c}{ Regional Police } & Drug-Related Crime \\
\hline 1 & Aceh & 934 \\
2 & North Sumatera & 2.668 \\
3 & West Sumatera & 299 \\
4 & Riau & 843 \\
5 & Jambi & 216 \\
6 & Sumatera Selatan & 1.209 \\
7 & Bengkulu & 179 \\
8 & Lampung & 1.663 \\
9 & Bangka Belitung & 94 \\
10 & Riau Island & 244 \\
11 & Metro Jaya & 5.400 \\
12 & West Java & 887 \\
13 & Middle of Java & 683 \\
14 & D.I.Yogyakarta & 143 \\
15 & East Java & 548 \\
\hline
\end{tabular}

19 Badan Pusat Statistik. Data Kejahatan Narkoba. 2014. 


\begin{tabular}{llc}
\hline No & \multicolumn{1}{c}{ Regional Police } & Drug-Related Crime \\
\hline 16 & Banten & 93 \\
17 & Bali & 320 \\
18 & West Nusa Tenggara & 151 \\
19 & East Nusa Tenggara & 6 \\
20 & West Kalimantan & 199 \\
21 & Middle Of Kalimantan & 234 \\
22 & South Kalimantan & 1.159 \\
23 & North Sulawesi & - \\
24 & South Sulawesi & 214 \\
25 & Southeast Sulawesi & 608 \\
26 & Gorontalo & 1 \\
27 & Maluku & 18 \\
28 & North Maluku & 8 \\
29 & Papua $\quad$ INDONESIA & 37 \\
& & 19.953 \\
\hline
\end{tabular}

Sumber: Biro operasi kontrol, Markas Besar Polisi
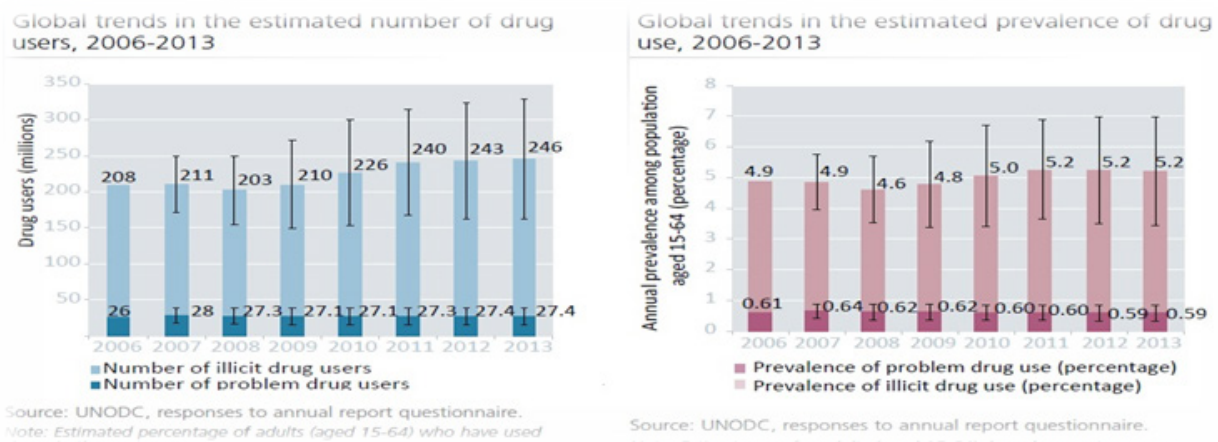

Gambar 2. Tahun 2015 laporan UNODC (Kantor PBB untuk Narkoba dan Kejahatan) mengatakan bahwa jumlah pengguna narkoba di tahun 2006 berdasarkan data yang 208 juta, dan meningkat tajam pada tahun 2013 sebanyak 246 juta.

Otak manusia terdiri dari 100 miliar sel saraf atau neuron. Tiap neuron mempunyai banyak serabut yang dinamakan dendrit dan axon, neuoron tersebut saling berhubungan dengan yang lain yang mencapai lebih dari 100 triliun sambungan yang dinamakan synapse Stimulus pada saraf dijalarkan dalam neuron secara elektrik dan darineuron ke neuron lain melalui synapse dengan bantuan zat kimia yang dinamakan neurotransmatter. ${ }^{20}$ Di dalam otak seseorang yang telah menjadi pecandu narkoba dalam waktu yang cukup lama akan mengalami kerusakan pada area orbitrofrontal, ${ }^{21}$ dan apabila terjadi gejala pemutusan pengonsumsian obat maka rasa mendambakan untuk mendapatkan rangsangan kembali akan menjadi lebih kuat. Sehingga dapat dikatakan bahwa gejala pemutusan untuk mengkonsumsi narkoba terdapat kemiripan dengan gejala putus cinta yang sangat mendalam, yang dimungkinkan para pecandu akan melakukan perbuatan bunuh diri atau perbuatan-perbuatan lainnya. Penyalahgunanaan narkoba dalam perspektif HAM (Hak asasi manusia) sangat identik dengan segala bentuk kejahatan yang merugikan diri pelaku dengan orang yang disekitarnya. Hal ini menyebabkan hak-hak manusia untuk mendapatkan rasa aman dan nyaman terhadap segala bentuk ancaman akan semakin berkurang seiring dengan merebaknya penyalahgunaan narkoba. Mengenai definisi

20 Joewana, Setya. Margiyanti, Lusi. Padmohoedojo, G.Lina. 2001. Petunjuk Praktis Keluarga Untuk Mencegah Penyalahgunaan Narkoba. Yogyakarta: Media Presindor. Hlm.27

21 Korteks orbitofrontal (OFC) adalah korteks prefrontal daerah di lobus frontal di otak yang terlibat dalam kognitif pengolahan pengambilan keputusan Wikipedia. 2016. "Korteks orbitofronta" (online), (https://en.wikipedia.org/wiki/Orbitofrontal_cortex.htm., diakses tanggal 5 Juni 2016). 
HAM, Jan Materson ${ }^{22}$ dalam Teaching Human Right menegaskan bahwa Hak Asasi Manusia adalah hak-hak yang melekat pada setiap manusia, yang tanpanya manusia mustahil dapat hidup sebagai manusia. Sedangkan Jhon locke menyatakan bahwa HAM adalah hak-hak yang diberikan langsung oleh Tuhan Yang Maha Pencipa sebagai hak yang kodrati. Oleh karena itu, pada dasarnya setiap hak asasi manusia wajib dilindungi, dipenuhi dan ditegakan oleh negara. Pentingnya perindungan HAM mencapai puncaknya pada Tahun 1948 ketika Perserikatan Bangsa Bangsa (PBB) memproklamirkan sebuah Deklrasi Universal Hak Asasi Manusia (DUHAM) yang secara mengesankan menjabarkan "hak tidak dapat dicabut dan diganggu gugat atas semua anggota manusia", deklarasi ini menandai tonggak bersejarah sebuah moral dalam dalam sejarah komunitas bangsa-bangsa. ${ }^{23}$ Hanya saja dalam perkembangannya, tidak semua hak harus dipenuhi beroperasi mutlak, ada pula hak-hak yang dapat dibatasi pemenuhannya dan ada hak-hak yang tidak tidak dapat dibatasi pemenuhannya meskipun dalam keadaan darurat. Hak-hak yang boleh dibatasi pemenuhannya dalam keadaan darurat yaitu hak yang disebut sebagai derogable rights, yang terdiri dari hak untuk menyatakan pendapat, hak untuk bergerak, hak untuk berkumpul, dan hak untuk berbicara. non-derogable rights (hak-hak yang bersifat absolut yang tidak boleh dikurangi pemenuhannya oleh negara-negara pihak, walaupun dalam keadaan darurat sekalipun) yang pada prinsipnya meliputi adalah hak untuk hidup, kebebasan dari tindakan penyiksaan, bebas dari tindakan yang tidak manusiawi dan merendahkan martabat, kebebasan dari perbudakan dan penghambaan, kebebasan dari undangundang berlaku surut, serta kebebasan berpikir, berhati nurani dan beragama. Hak asasi yang penulis sebutkan diatas disebut dengan intisari (hardcore) Hak asasi Manusia, artinya itulah hak asasi manusia yang utama yang tidak boleh hilang dalam diri manusia dan hak inilah yang selalu dipertahankan dari diri manusia. ${ }^{24}$ Dengan demikian, Hak asasi manusia merupakan pemberian dari Tuhan Yang Maha Esa, sebagai konsekuensi dari manusia adalah ciptaannya, sehingga tidak dapat dirampas atau dihapuskan oleh siapapun termasuk di dalamnya adalah oleh negara. Negara berkewajiban untuk menanggung beban atau bertanggung jawab untuk penghormatan, pemenuhan dan perlindnugan hak-hak asasi manusia bagi seluruh warga negaranya. Dalam konteks negara hukum, telah jelas bahwasanya hak asasi manusia merupakan salah satu pilar dalam mewujudkan sebuah negara hukum, yaitu dengan ditegakanya hak asasi manusia. Indonesia sebagai negara hukum telah mengatur hak asasi mausia didalam konstitusinya yaitu Undang-Undang Dasar 1945 Pasal 1 Ayat 3 "Negara Indonesia Adalah Negara Hukum".

Kejahatan penyalahgunaan narkoba terhadap Hak Asasi Manusia harus segera ditangani dan diatasi melalui sinergitas gerakan pencegahan yang dilakukan oleh seluruh komponen masyarakat. Pemerintah dapat berperan aktif dengan upaya-upaya penegakan hukum bagi mereka yang terbukti menyalahgunakan narkoba apapun jenisnya. Konvensi tunggal narkotika 1961, beserta hasil dari united nations conferencee for adaption of a single convention on narcotic drug, yang diselnggarakan di New York dari tanggal 24 Januari sampai dengan 31 Maret 1961, bertujuan untuk menciptakan suatu kovensi internasional terhadap pengawasan internasional atas narkotika, menyempurnakan cara-cara pengawasan dan membatasi penggunaannya hanya untuk kepentingan pengebatan dan atau ilmu, pengetahuan, serta menjamin kerja sama internasional dalam pengawasan narkotika tersebut. Setelah kovensi tunggal narkotika 1961, selanjutnya dikeluarkan resolusi the united nation economic and social council Nomor: 1474, tanggal 24 Maret 1970, maka pada tanggal 21 februari 1971, di Wina Austria, deselenggarakan the united nation conference for the adoption of a protocol on psychotropic substance, telah manghasilkan convention on psychotropic substance 1971.

22 Jan Materson dari komisi Hak Asasi Manusia PBB. Green Mind Community. 2009. Teori dan Politik Hukum. Yogyakarta: Total Media. Hlm. 270

23 Green Mind Community. 2009. Teori dan Politik Hukum. Yogyakarta: Total Media. Hlm. 271

24 Matompo, Osgar.S. 2014.Pembatasan Terhadap Hak Asasi Manusia Dalam Perspektif Keadaan Darurat. Vol.21 No. 1 . 2014; pp.57-60 
Upaya preventif sangat diperlukan guna melindungi generasi muda sebagai penerus kelangsungan hidup manusia, tindakan-tindakan konkret yang dimulai dari pencegahan dan membentengi generasi muda agar tidak masuk dan terjerumus dalam jurang penyalahgunaan narkoba. Adagium yang menyatakan bahwa "sedia payung sebelum hujan, agar tidak menjadi basah kuyup oleh air hujan" mengisyaratkan agar kita sebagai masyarakat yang baik harus proaktif dalam mencegah penyalahgunaan narkoba, dengan mengetahui urgensi dari permasalahan, maka penyalahgunaan narkoba dapat segera di hentikan. Melalui pendidikan dan penyampaian informasi yang masif dan akurat merupakan langkah-langkah yang tidak kalah pentingnya untuk mencegah penyalahgunaan narkoba, dan di satu sisi terus menyuarakan pemerintah untuk membasmi para pengedar narkoba. Bagi mereka yang terlanjur jatuh dalam lubang narkoba, masih dapat diberi harapan untuk memperbaiki diri melalui rehabilitasi.

\section{Penutup}

\section{Kesimpulan}

Narkoba ( Narkotika dan obat berabahaya) adalah semua bahan obat yang mempunyai efek kerja yang bersifat membiuskan menurunkan kesadaran (depressant), merangsang meningkatkan prestasi (stimulans), menagihkan ketergantungan (dependence), menghayalkan (halusinasi). Perkembangan kejahatan narkoba telah menakutkan kehidupan masyarakat yang telah memakan beribu-ribu korban, tanpa memandang umur dan status sosial. Ironisnya, yang menjadi korban mayoritas adalah kalangan remaja dan pemuda yang merupakan generasi penerus bangsa. Fenomena ini menyadarkan kita bahwa penyalahgunaan narkoba merupakan tanggungjawab negara dan masyarakat. Penyalahgunaan narkoba bukanlah suatu kejadian sederhana yang bersifat mandiri, melainkan merupakan akibat dari berbagai faktor yang secara kebetulan terjalin menjadi sautu fenomena yang sangat merugikan bagi semua pihak yang terkait. Keberadaan narkoba yang disalahgunakan akhir-akhir ini sangat marak dan justru membahayakan. Kehidupan seseorang yang semula baik, disiplin, tekun bealajar atau bekerja, mau memperhatikan orang lain, suka menolong, dan lain-lain, dapat berubah menjadi seratus delapan puluh derajat kearah yang buruk, dia tidak lagi mau memperhatikan orang lain, pikirannya hanya tertuju bagaimana ia memperoleh narkoba untuk memenuhi kebutuhannya, artinya membuat seseorang baik-baik menjadi penjahat dan bahkan sampah masyarakat. Oleh karena itu, perlu adanya penanggulangan narkoba secara komprehensif dengan menitikberatkan serta masyarakat serta pengembangan sikap para penegak hukum secara intensif. Terhadap kejahatan hak asasi manusia Secara umum kejahatan sendiri memiliki pengertian sebagai suatu/tindakan anti sosial yang merugikan, tidak pantas, tidak dapat dibiarkan, yang dapat menimbulkan kegoncangan dalam masyarakat, sedangkan Hak asasi manusia merupakan pemberian dari Allah SWT, sebagai konsekuensi dari manusia adalah ciptaan Allah SWT, sehingga tidak dapat dirampas atau dihapuskan oleh siapapun termasuk didalamnya adalah negara. Dengan demikian, penyalahgunaan narkoba sebagai kejahatan hak asasi manusia mengandung arti bahwasannya segala bentuk penyalahgunaan narkoba dapat dikategorikan sebagai sebuah kejahatan yang merugikan dan dapat menimbulkan kegoncangan dalam masyarakat yang secara tidak langsung akan mengancam hak-hak asasi manusia lainnya dalam pergaulan hidup masyarakat dan akan mempengaruhi keberlangsungan dan eksistensi umat manusia kedepannya.

\section{Daftar Purtaka}

Badan Narkotika Nasional. 2010. Pelajar dan Bahaya Narkotika. Jakarta: BNN

Badan Pusat Statistik. 2014. Data Kejahatan Narkoba.

B. Simanjuntak. 1981. Beberapa Aspek Patologi Sosial. Bandung: Alumni.

Green Mind Community. 2009. Teori dan Politik Hukum. Yogyakarta: 
Total Media.

Joewana, Setya. Margiyanti, Lusi. Padmohoedojo, G.Lina. 2001. Petunjuk Praktis Keluarga Untuk Mencegah Penyalahgunaan Narkoba. Yogyakarta: Media Presindor.

Nazir, Moh. 1998. Metode Penelitian. Jakarta: ghalia Indonesia.

Retnaningsih, Ekowati. 2013. Akaes Layanan Kesehatan. Depok: Rajagrafindo.

Ray, Oakley. Ksir, Charles. 1999. Drugs, Society, And Human Behavior, Eigth Edition. USA: Von Hoffmann Press.

Setiadji, V.Sutarmo. 2007. Awas Jangan Coba-Coba Menjadi Pengguna

Narkoba Berbahaya!. Jakarta : Universitas Indonesia Press.

Soetomo. 2008. Masalah Sosial dan Upaya Pemecahannya. Yogyakarta: Pustaka Belajar.

Sunarso, Siswantoro. 2004. Penegakan Hukum Psikotropika Dalam Kajian Sosiologi Hukum. Jakarta: Raja Grafindo Persada.

UNODC. World Drug Report in 2015 Yanny, L. Dewi. 2002. Narkoba, Pencegahan dan Penangannya. Jakarta: Elex Media Komputindo

\section{Jurnal}

Matompo, Osgar.S. 2014.Pembatasan Terhadap Hak Asasi Manusia Dalam PerspektifKeadaan Darurat. Vol.21 No. 1 . 2014; pp.57-60

\section{Internet}

Wikipedia. 2016. "Korteksorbitofronta" (online), (https://en.wikipedia.org/wiki/ Orbitofrontal_cortex.htm.,diakses tanggal 5 Juni 2016).

Wikipedia. 2016. "Hippie" (online), (https://id.wikipedia.org/wiki/Hippie.htm, diakses tanggal 31 Mei 2016).

Wikipedia. 2016. "Perang Saudara Amerika Serikat" (online), （https://id.wikipedia.org/ wiki/Perang_Saudara_Amerika_Serikat. $\quad$ htm, Diakses tanggal 31 Mei 2016). 